\title{
BUDAYA SIRIH PINANG DAN PELUANG PelestarianNya dI sumba barat, INDONEsIa*
}

\section{SIRIH PINANG CULTURE AND OPPORTUNITIES OF ITS PRESERVATION IN WEST SUMBA, INDONESIA}

\author{
Arief Dwinanto $^{1}$, Rini S. Soemarwoto ${ }^{2}$, Miranda Risang Ayu Palar ${ }^{3}$ \\ Program Studi Antropologi, Pascasarjana FISIP, Universitas Padjadjaran ${ }^{1,2}$ \\ Program Studi Ilmu Hukum, Pascasarjana Fakultas Hukum, Universitas Padjadjaran ${ }^{3}$ \\ E-mail: ariefdw@gmail.com ${ }^{1}$, rinisoemarwoto@gmail.com ${ }^{2}$, miranda.risang.ayu@ unpad.ac.id ${ }^{3}$
}

Naskah Diterima:15 Juli $2019 \quad$ Naskah Direvisi:19 September $2019 \quad$ Naskah Disetujui : 28 September 2019

DOI: 10.30959/patanjala.v11i3.543

\begin{abstract}
Abstrak
Sirih pinang dalam tulisan ini mengacu pada sirih (Piper betle L), pinang (Areca catechu L) dan kapur; serta praktik mengunyahnya. Di berbagai daerah di Indonesia, budaya sirih pinang dan nilai-nilai budaya yang terkandung di dalamnya mulai pudar. Namun di Sumba, masyarakatnya masih menanam sirih - pinang dan memanfaatkan sirih pinang dalam kesehariannya, menggunakannya pada praktik ritual dan acara seremonial. Penelitian ini membahas budaya sirih pinang di Sumba Barat. Kajian ini menggunakan pendekatan kualitatif. Pengumpulan data menggunakan metode observasi, wawancara mendalam dan kajian pustaka. Kajian ini menemukan bahwa sirih pinang di Sumba Barat memiliki beragam fungsi sosial, budaya, ekonomi dan pengobatan. Sirih pinang menjadi simbol penting dalam budaya Sumba. Hal ini terkait erat dengan tatanan yang memengaruhi kehidupan orang Sumba, yaitu kepercayaan Marapu, tempat tinggal (rumah: uma ; dan kampung: wano), serta ikatan kekerabatan (kabisu). Sirih pinang sebagai sumber daya budaya tak benda berpotensi untuk dapat dilindungi dalam kerangka pelestarian budaya melalui sistem perlindungan hukum sumber daya budaya takbenda, yaitu melalui ranah warisan budaya takbenda (WBTB) di Indonesia.
\end{abstract}

Kata kunci: sirih pinang, budaya Sumba, pelestarian budaya, warisan budaya takbenda.

\section{Abstract}

Sirih pinang refers to the material (betel nut, areca nut, lime) and its practice of chewing it. Sumbanese, plant and use sirih pinang in their daily lives, and use it in ritual practices and ceremonial events. In various regions in Indonesia, sirih pinang tradition and it's cultural values began to fade, therefore efforts to preserve sirih pinang tradition are needed. This study uses a qualitative approach. Data collection is carried out through observation, interviews, and literature studies. The results found that sirih pinang has a variety of social, cultural, economic, and medicinal functions. It has become an essential symbol in sumbanese culture. The symbol is related to the system that affects the lives of sumbanese, namely Marapu's beliefs, kampung (village) or uma (rumah) and kabisu (kinship system). In the intellectual property rights system, sirih pinang can be categorized as an intangible cultural resource that can be protected, utilized and developed within the framework of cultural preservation. One of the opportunities of the effort to preserve the intangible cultural resources is through the recognition and acknowledgement of sirih pinang as a shared intangible cultural heritage (ICH) in Indonesia.

Keywords: sirih pinang, Sumbanese culture, cultural preservation, intangible cultural heritage.

* Artikel ini merupakan bagian dari naskah tesis Arief Dwinanto, Program Studi Antropologi, Pascasarjana Fakultas Ilmu Sosial dan Ilmu Politik, Universitas Padjadjaran, 2019. 


\section{A. PENDAhuluan}

Sirih pinang dalam tulisan ini mengacu pada kata benda, yaitu tanaman sirih (ppiper betle l.), pinang (Aaeca catechu 1.) dan kapur; serta kata kerja, yaitu praktik mengunyah (sirih-pinang dan kapur)-nya yang dilakukan penduduk dalam kehidupan sehari-hari.

Dalam penelitian mengenai sirih dan pinang yang telah dilakukan sebelumnya, ditemukan bahwa sirih dan pinang memiliki beragam fungsi yang berhubungan dengan aspek sosial, ekonomi, budaya, dan kesehatan masyarakat (Burkill, 1935; Reid, 1985; Heyne, 1987; Ellen, 1991; Rooney, 1995; Solihin, 2018). Sehingga dianggap memiliki arti penting dalam kehidupan masyarakat di berbagai kebudayaan di wilayah Asia Tenggara (termasuk Indonesia) (Burkill, 1935; Reid, 1985; Rooney, 1995; Reid, 2014: 49-53). Sirih pinang juga memiliki beragam penyebutan sesuai bahasa daerahnya yang menandakan kedua tanaman ini merupakan tanaman lokal yang ada di daerah tersebut (Reid, 1985: 529; Heyne, 1987).

Saat ini, di berbagai wilayah di Nusantara, praktik budaya sirih pinang telah berkurang dan mengakibatkan memudar ataupun hilangnya nilai-nilai budaya yang terkandung di dalam tradisi tersebut, seperti terjadi di Manggarai (Saka, 2001) dan di budaya Melayu (Solihin, 2018). Selain itu, dari aspek keanekaragaman hayati, seperti yang terjadi di Jawa Barat, disebutkan bahwa berkurangnya tanaman pinang di wilayah tersebut disebabkan oleh menurunnya penggunaan pinang dalam keseharian masyarakatnya (Iskandar dkk., 2018: 574).

Sementara itu, di Sumba, Nusa Tenggara Timur, masyarakatnya masih menanam, mengelola, memanfaatkan dan mengkonsumsi sirih pinang dalam kesehariannya, serta menggunakannya pada praktik ritual dan acara seremonial.

Penelitian terkait sirih pinang di Indonesia telah banyak yang melakukannya, diantaranya ialah mengenai etnobotani sirih pinang di wilayah Nuaulu, Seram Tengah (Ellen, 1991) dan di Ruteng, Manggarai (Saka, 2001); serta mengenai pemaknaan budaya sirih pinang di Kota Manokwari, Papua (Nugroho, 2016). Sementara itu, penyebutan terkait penggunaan sirih pinang di wilayah Sumba, tersebar dalam berbagai kajian tentang Sumba, namun tidak menjadi fokus studinya (Forth, 1981; Rothe, 2004; Vel, 2010; Barokah, 2016). Hal tersebut mengindikasikan arti penting sirih pinang dalam kehidupan orang Sumba.

Berangkat dari gambaran tersebut di atas, maka menarik untuk dibahas mengenai bagaimana budaya sirih pinang di Sumba. Di samping itu, berkaitan dengan fenomena memudar dan menghilang nilai budaya yang terkandung dalam budaya sirih pinang, yang memiliki fungsi sosial, ekonomi, budaya dan kesehatan, maka kiranya diperlukan suatu upaya pelestarian

Menurut Sedyawati, prinsip dari pelestarian budaya ialah "pada dasarnya berarti keseluruhan upaya untuk membuat suatu kebudayaan lestari eksistensinya, dan bukan semata wujud-wujud ekspresinya" (2014: 223). Selanjutnya dikatakan bahwa pelestarian mengandung makna: upaya perlindungan (terhadap penggunaan tidak sah atau tanpa hak; dan perlindungan terhadap kepunahan), upaya pengembangan dan pemanfaatan (Sedyawati, 2014: 223-227).

Salah satu cara dalam upaya untuk melindungi budaya sirih pinang yang memiliki beragam fungsi tersebut ialah melalui sistem perlindungan hukum. Dalam hal ini berupa perlindungan hukum sumber daya budaya takbenda.

Kriteria dari objek sumber daya budaya takbenda, yang dibedakan dari objek HKI (Hak Kekayaan Intelektual) konvensional, menurut Blankeney ialah: (1) ditandai dengan nilainilai tradisional, cara berpikir tradisional, bentuk tradisional dan gaya tetap, dan konteks tradisional; (2) digunakan secara 
aktif oleh masyarakat adat dan komunitas lokal, kelompok, dan dalam beberapa kasus, individu sebagai living culture; (3) dipelihara, digunakan, dikembangkan, dan ditransmisikan dari generasi ke generasi di dalam dan di luar komunitas; (4) sangat dipengaruhi oleh lingkungan di mana masyarakat adat atau komunitas lokal bergantung untuk mata pencaharian mereka; dan (5) melayani rasa identitas sosial dan budaya masyarakat (Blankeney, 1999 dalam Gervais, 2003: 7 dikutip Ayu Palar, 2018: 222).

Salah satu dari sistem perlidungan hukum terkait sumber daya budaya takbenda tersebut ialah warisan budaya takbenda (Ayu Palar, 2018:221). Warisan budaya takbenda berdasarkan pada Konvensi UNESCO ${ }^{2}$ tahun 2003 (Convention for the Safeguarding of the Intangible Cultural Heritage), yang telah diratifikasi oleh Indonesia pada tahun 2007, melalui Peraturan Presiden Nomor 78 tahun 2007 tentang Pengesahan Konvensi UNESCO 2003 tentang perlindungan warisan budaya takbenda (Convention for the Safeguarding of Intangible Cultural Heritage). Kemudian, pada tahun 2013, disahkan Peraturan Menteri Pendidikan dan Kebudayaan Republik Indonesia, Nomor 106 Tahun 2013 tentang Warisan Budaya Takbenda Indonesia sebagai dasar pelaksanaannya.

Dalam Buku Panduan Praktis Pencatatan Warisan Budaya Takbenda Indonesia (Waluyo, dkk, 2009: 13), disebutkan bahwa Warisan Budaya Takbenda menurut Pasal 2 Ayat 1 Konvensi UNESCO tahun 2003 (Convention for the Safeguarding of the Intangible Cultural Heritage), didefinisikan sebagai:

"Segala praktek, representasi, ekspresi, pengetahuan, keterampilan--serta alat-alat, benda (alamiah), artefak dan ruang-ruang budaya terkait dengannya--yang diakui oleh berbagai komunitas, kelompok, dan dalam hal tertentu perseorangan sebagai bagian warisan budaya mereka. Warisan budaya takbenda ini, yang diwariskan dari generasi ke generasi, senantiasa diciptakan kembali oleh berbagai komuniti dan kelompok sebagai tanggapan mereka terhadap lingkungannya, interaksinya dengan alam, serta sejarahnya, dan memberikan mereka rasa jati diri dan keberlanjutan, untuk memajukan penghormatan keanekaragaman budaya dan daya cipta insani. Untuk kepentingan Konvensi ini, pertimbangan akan diberikan hanya kepada warisan budaya takbenda yang cocok dengan perjanjian-perjanjian internasional yang ada mengenai hak-hak asasi manusia, serta segala persyaratan saling menghormati antara berbagai komunitas, kelompok, dan dalam hal tertentu perseorangan".

Konvensi UNESCO tahun 2003 mengenai warisan budaya takbenda ini bersifat perlindungan non-ekonomis dan mengandung makna perlindungan yang bersifat inklusif (Ayu dkk., 2017: 211). Sistem perlindungan ini didesain untuk menguatkan dan menjaga melalui pengakuan akan hak sosial budaya komunitas pengampunya (Ayu Palar, 2018). Tujuan dari warisan budaya takbenda ini ialah upaya pelestarian budaya.

Terkait dengan uraian tersebut di atas, tulisan ini membahas tentang bagaimana budaya sirih pinang di Sumba dan peluang pelestariannya. Penelitian ini mengambil studi kasus di Kelurahan Sobawawi, Kecamatan Loli, Kabupaten Sumba Barat, Nusa Tenggara Timur.

${ }^{2}$ United Nations Educational, Scientific and

Cultural Organization

Patanjala, ISSN 2085-9937 (print), ISSN: 2598-1242 (online) 


\section{B. METODE PENELITIAN}

Metode penelitian yang digunakan dalam penelitian ini bersifat deskriptif kualitatif melalui pengumpulan data primer dan data sekunder. Data primer didapatkan melalui penelitian lapangan dengan cara observasi dan wawancara mendalam terhadap informan. Informan dipilih melalui petunjuk informan pangkal yaitu tokoh adat dan kepala desa. Selanjutnya informan diambil dengan menggunakan teknik snow ball. Informan yang diwawancarai terdiri dari tokoh adat, kepala kabisu, tokoh masyarakat, pemilik tanaman sirih-pinang, pedagang sirihpinang, penyembuh tradisional dan warga yang mengkonsumsi sirih pinang. Selain itu, diwawancara juga staf dari Dinas Kebudayaan dan Pariwisata, serta staf dari Badan Penelitian dan Pengembangan Kabupaten Sumba Barat.

Observasi dilakukan dengan mengikuti acara keluarga orang Sobawawi dan kegiatan sosial, seperti bertamu ke rumah, ikut serta mengambil sirih pinang di kebun, melayat kedukaan orang yang meninggal, berbelanja sirih pinang ke warung dan pasar; serta lain sebagainya. Sedangkan data sekunder diperoleh melalui studi pustaka dan data tertulis yang didapat dari instansi terkait.

Analisis data menggunakan pendekatan kualitatif. Caranya ialah dengan menginterpretasikan data yang bersamaan waktunya dengan tahap pengumpulan data. Proses analisis data kualitatif ini terdiri atas tiga tahap kegiatan, yaitu : reduksi data, penyajian data, serta penulisan kesimpulan dan verifikasi. Ketiga tahapan ini dilaksanakan pada saat 'sebelum', 'sewaktu' dan 'setelah' pengumpulan data (Huberman \& Miles, 2009: 592).

Lokasi penelitiannya ialah di Kelurahan Sobawawi, Kecamaan Loli, Kabupaten Sumba Barat, Nusa Tenggara Timur. Pemilihan lokasi ini dengan pertimbangan bahwa di Sobawawi penduduknya mayoritas orang Sumba dan masih melakukan budaya sirih pinang dalam kehidupan sehari-harinya.

\section{HASIL DAN BAHASAN}

\section{Gambaran Umum Lokasi Penelitian}

Sobawawi merupakan salah satu kelurahan di Kecamatan Loli Kabupaten Sumba Barat, Nusa Tenggara Timur. Posisinya secara geografis terletak di Pulau Sumba. Secara administratif terdapat empat kabupaten di Pulau Sumba, yaitu Sumba Barat, Sumba Timur, Sumba Barat Daya dan Sumba Tengah. Kedua kabupaten terakhir yang disebutkan ialah hasil pemekaran dari Kabupaten Sumba Barat pada tahun 2007.

Kabupaten Sumba Barat yang beribu kota di Waikabubak, terbagi atas enam kecamatan, yaitu Lamboya, Wanokaka, Laboya Barat, Loli, Kota Waikabubak dan Tana Righu. Luas daerah Sumba Barat mencapai $737 \mathrm{~km}^{2}$ dengan sebagian besar wilayahnya berbukit-bukit. Sementara itu, Kecamatan Loli sendiri memiliki luas wilayah $132,36 \mathrm{~km}^{2}$ yang terbagi atas 14 desa/kelurahan.
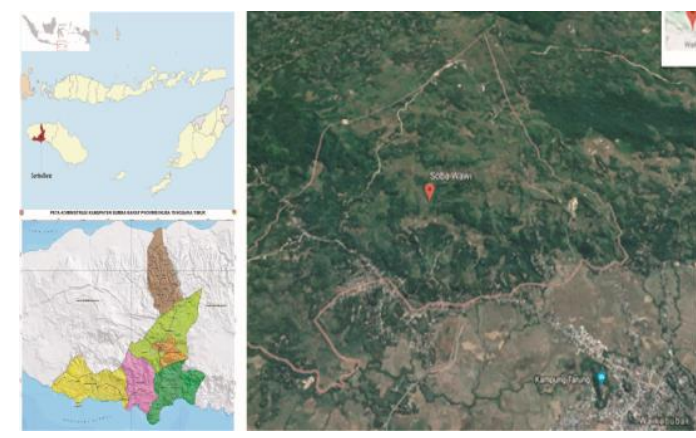

Gambar 1. Peta Sobawawi di Kabupaten Sumba Barat, Provinsi Nusa Tenggara Timur

Kelurahan Sobawawi memiliki luas wilayah $17,90 \mathrm{~km}^{2}$ dengan tipologi berupa perbukitan dan beriklim tropis. Jumlah penduduknya mencapai 4736 jiwa, terdiri dari 2435 laki-laki dan 2301 perempuan, yang tersebar di $10 \mathrm{RW}$ dan 22 RT. Hal ini berarti kepadatan penduduknya ialah $265 \mathrm{jiwa} / \mathrm{km}^{2}$. Sobawawi berjarak $8 \mathrm{~km}$ dari pusat 
pemerintahan kecamatan dan $3 \mathrm{~km}$ dari pusat pemerintahan kota kabupaten. Secara umum, mata pencaharian mayoritas penduduk Kelurahan Sobawawi ialah petani sawah dan kebun.

Secara administratif, Sobawawi sebagai sebuah kelurahan terbentuk pada 1993, dimana sebelumnya merupakan sebuah desa. Secara tradisional, Sobawawi termasuk ke dalam wilayah adat (domain) Loli (yang kini juga menjadi nama satu kecamatan di Kabupaten Sumba Barat). Menurut tokoh adat setempat, nama Sobawawi berasal dari bahasa Loli yang berarti sebuah genangan air tempat babi-babi mencari minum (soba: genangan air, wawi: babi). Lokasinya berada di bawah Kampung Tarung dan Kampung Waitabar. Kedua kampung ini merupakan kampung besar (wanno kalada) bagi orang Loli, khususnya warga Sobawawi. Kampung besar (induk) asal nenek moyang mereka, yang memiliki hubungan kekerabatan seketurunan ataupun melalui perkawinan. Sebagaimana

perkembangan pola permukiman di Sumba pada umumnya, bermula dari sebuah kampung besar (wanno kalada), kemudian karena jumlah penduduknya bertambah, serta untuk kemudahan mendekati sumber penghidupannya mengolah lahan pertanian dan berternak hewan, mereka mendirikan rumah kebun (uma ouma). Setelah rumah-rumah kebun ditinggali secara permanen dan berkumpul berdekatan yang terdiri dari beberapa rumah, berdirilah kampung yang biasa disebut wanno gollu. Begitulah cikal bakal pemukimanpemukiman di Sobawawi, bermula dari wanno kalada, wanno gollu dan uma ouma.

Kampung besar merupakan kampung induk tempat rumah besar (uma kalada) beberapa kabisu (klen) berada. Tempat di mana leluhur mereka tinggal semasa hidup, dan dimakamkan dalam kubur batu di tengah kampung. Kerabat yang tinggal di luar kampung besar, secara rutin datang ke kampung besarnya jika ada ritual adat maupun acara terkait dengan kabisu-nya.

Penduduk Sobawawi, sebagaimana pada umumnya orang Sumba, terorganisir ke dalam kelompok kekerabatan patrilineal eksogam yang disebut kabisu (patriclan) ${ }^{3}$. Sebuah klen patrilineal (patriclan) terdiri atas sekelompok laki-laki yang memiliki hubungan kekerabatan seketurunan secara patrilineal beserta semua perempuan yang mereka kawini dan anak lelaki mereka; beserta anak perempuan yang belum menikah.

Orang Sumba memiliki pandangan dunia berdasarkan kepercayaan Marapu, yaitu suatu kepercayaan lokal Sumba yang merupakan warisan dari nenek moyang mereka. Kepercayaan ini yang menjadi fondasi utama dari budaya Sumba. Meskipun kini telah banyak orang Sumba yang menganut agama ${ }^{4}$ seperti Kristen Protestan, Katolik, Islam, namun dalam kegiatan atau upacara adat Sumba, warganya masih ikut berperan serta karena terkait adat, hubungan kekerabatan dan kepentingan komunal ${ }^{5}$.

Dalam kepercayaannya, mereka meyakini bahwa semua makhluk hidup memiliki jiwa; dan jiwa orang yang

3 Exogamic patrilineal kinship groups (Onvlee, 1983: 152).

4 Di Sumba Barat, pada tahun 2017, jumlah penganut agama Islam (10.476), Protestan (73.911), Katolik (32.330), Hindu (353), Budha (16), Lainnya (12.946) (Kabupaten Sumba Barat Dalam Angka 2018). Sementara itu, di Kecamatan Loli, jumlah penganut agama Islam (2.000), Protestan (15.607), Katolik (8.328), Hindu (11), Budha (-), Lainnya/Marapu (2.648) (Kecamatan Loli Dalam Angka 2018). Menurut keterangan staf kelurahan pada tahun 2018, penganut kepercayaan Marapu di Sobawawi sekitar 20 persen dari jumlah penduduknya.

5 Tulisan Soeriadiredja (2013) menjadi rujukan untuk memahami bagaimana gambaran praktik terkait agama dan adat oleh orang Sumba. 
sudah meninggal tetap ada dan tinggal di dalam rumah, melakukan aktivitas seperti orang hidup. Sementara itu, dalam kosmologi orang Sumba, dunia terbagi ke dalam tiga bagian, yaitu dunia atas (tempat para dewa dan roh leluhur), dunia tengah (tempat manusia hidup) dan dunia bawah (tempat hewan). Hal ini terepresentasikan dalam bentuk rumah tradisional Sumba (Uma) di Sobawawi yang terdiri dari tiga tingkatan yaitu uma dana (bagian atas/menara yang digunakan untuk lumbung penyimpanan bahan makanan hasil panen dan pusaka leluhur), katunga (bagian tengah tempat tinggal orang hidup sehari-hari) dan Salakabunga (bagian bawah sebagai kandang hewan peliharaan).

Budaya orang Sumba pada beragam aspeknya tertata oleh kepercayaan Marapu, tempat kediaman (kampung dan Uma), serta ikatan kekerabatan (Kabisu) (Soeriadiredja, 2013). Marapu, dari segi etimologi berasal dari kata $m a=$ Yang dan $r a p u=$ dihormati, disembah, didewakan (Onvlee dikutip Kapita 1976, dalam Bamualim 2017:30). Marapu ialah sistem kepercayaan yang meyakini keberadaan kekuatan tertinggi yang disebut Mawolu-Marawi. MawoluMarawi secara harafiah berarti yang membuat dan yang menciptakan. Nama dan wujudnya tidak diketahui, tetapi keberadaannya diyakini. Dalam bahasa Sumba disebut juga ndapa nunga ngara, ndapa teki tamo (yang tak disebut nama, tak ada bandingannya). Dalam kepercayaan Marapu, untuk memohon sesuatu dan mengetahui kehendak Mawolu-Marawi, diperlukan perantara marapu (roh leluhur yang dianggap telah dekat dengan sang pencipta) dalam ritualnya. Marapu sendiri tidak secara khusus mengacu pada roh leluhur atau dewa, tetapi lebih pada sifat suatu benda yang memiliki kekuatan supranatural, dikeramatkan dan disucikan (Bamualim, 2017, 32). Budaya orang Sumba di Sobawawi seperti pada umumnya orang Sumba tersebut di atas.

\section{Budaya Sirih - Pinang}

Penduduk Sobawawi, Loli, Sumba Barat menanam dan mengkonsumsi Sirih pinang dalam kesehariannya, serta menggunakannya pada beragam praktik ritual dan acara adat. Bahan utama untuk sajian sirih-pinang terdiri atas tiga macam, yaitu buah sirih, buah pinang dan kapur.

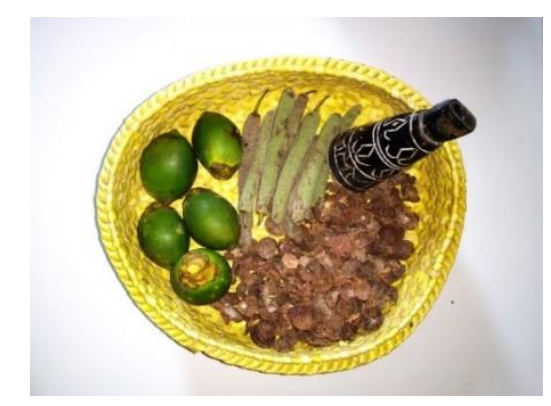

Gambar 2. Penyajian sirih-pinang. Kuolaka (wadah terbuat dari anyaman daun pandan atau lontar) yang berisi buah sirih, buah pinang muda, irisan pinang kering dan tempat kapur berbahan tanduk kerbau. Sumber: Arief, 2019.

Dalam bahasa Loli, sirih disebut dengan kata utta. Sirih untuk keperluan sirih pinang biasa disebut utta pia yang berarti pinang sendiri - di Loli. Tanaman sirih biasa ditanam di halaman rumah, kaliwo (kebun campuran di belakang rumah), ouma (kebun) dan pinggir sawah. Selain itu ada juga yang tumbuh secara alami, tanpa dengan sengaja ditanam. Masyarakat Loli mendapatkan buah sirih dari hasil mengambil sendiri dari pohon milik pribadi ataupun membelinya dari pedagang. Cara memanen buah sirih dilakukan dengan memetiknya langsung dengan tangan, ataupun menggunakan alat bantu berupa tangga bambu atau jolok (galah) bambu jika letak buahnya berada di ketinggian. Tanaman sirih sebagai tanaman merambat yang tumbuh mengikuti tanaman yang dirambatinya, terkadang dapat mencapai tinggi hingga lebih dari 7 meter sesuai pohon yang ditumpanginya. 
Dalam bahasa Loli, pinang disebut winno. Pinang untuk keperluan sirih pinang ialah winno dou yang berarti pinang lokal - di Loli. Tanaman pinang biasa ditanam di halaman rumah, kaliwo (kebun campuran di belakang rumah), ouma (kebun) dan pinggir sawah. Selain itu ada juga yang tumbuh secara alami, tanpa sengaja ditanam. Warga mendapatkan buah pinang dari hasil mengambil sendiri dari pohon miliknya ataupun membelinya dari pedagang. Buah pinang dipanen dengan cara memetiknya langsung menggunakan tangan ataupun memakai alat bantu berupa pisau atau parang. Sedangkan alat bantu untuk memanjat pohonnya ialah dengan menggunakan seutas tali yang dikaitkan pada kedua telapak kakinya sebagai penahan pijakan ketika memanjat. Selain itu, ada juga yang memanjat pohon pinang tanpa alat bantu apa pun. Tinggi pohon pinang dapat mencapai 12 meter lebih.

Buah pinang yang disajikan untuk bersirih pinang ialah pinang muda (pinang segar dan masih ada kulitnya) dan pinang kering. Pinang muda dikonsumsi dengan terlebih dahulu membuka kulit buahnya, kemudian langsung digigit isi buahnya. Pinang kering ialah buah pinang yang telah dikupas dan isinya diiris kecil-kecil menggunakan pisau serta dijemur beberapa hari dengan bantuan sinar matahari hingga kering. Pengeringan tersebut dimaksudkan agar pinang menjadi awet (tahan lama) serta mudah dibawa ke mana-mana.

Kapur digunakan sebagai campuran sirih pinang untuk menambah rasa dan memerahkan warna kunyahannya. Kapur untuk bersirihpinang ada dua jenis, yaitu kapur batu dan kapur laut. Kapur batu ialah kapur yang bahan dasarnya berupa batu kapur di sekitar Loli yang pengolahannya dengan cara dibakar menggunakan kayu bakar dan jika ada dicampur pula dengan kotoran kerbau yang sudah kering.
Sedangkan kapur laut merupakan kapur yang berasal dari daerah pesisir pantai Sumba. Kedua jenis kapur ini biasa diperjualbelikan dalam bentuk serbuk oleh pedagang sirih pinang. Sensasi rasa dari kapur laut lebih panas daripada kapur batu.

Orang Sobawawi, mengkonsumsi sirih-pinang dengan cara menggigit dan mengunyah buah pinang, bersamaan dengan buah sirih secukupnya. Buah sirih dipatahkan dan ujung patahannya ditutulkan pada kapur secukupnya dan dikunyah. Takaran ketiga jenis bahan utama sirih pinang disesuaikan dengan selera masing-masing orang. Hal yang patut diingat ialah jangan terlalu banyak campuran kapurnya, karena dapat mengakibatkan rasa panas berlebihan dan luka di mulut. Sirih-pinang terus dikunyah dan sekali-kali air liur yang keluar diludahkan. Rasa dari sirih pinang ialah agak sepat dengan sensasi hangat. Jika rasanya sudah tidak ada, maka ampas sirih-pinang yang ada di mulut dibuang. Sirih pinang dipercaya pula memiliki khasiat bagi kesehatan, yaitu untuk menguatkan gigi. Selain itu, dipercaya juga dapat menghadirkan rasa nyaman dan ketagihan bagi penggunanya. Hal tersebut menurut Rudgley, berhubungan dengan kandungan stimulan psikoaktif dari kedua tanaman yang mengandung arecaidine (Rudgley, 2005: 193).

Selain segi manfaatnya, terdapat juga efek mabuk bagi orang yang tidak kuat mengonsumsinya. Gejalanya berupa pusing, berkeringat dingin dan lemas. Efek mabuk tersebut, di samping karena orang yang memakannya tidak kuat terhadap rasa dan kandungan dari sirihpinang. Dapat juga disebabkan oleh pelanggaran pemali ketika memanen pinang dari pohonnya. Orang Sobawawi percaya bahwa ada cara tertentu untuk mengambil buah pinang yang baik dan benar. Jika hal tersebut dilanggar, maka akan menyebabkan efek mabuk bagi yang mengonsumsi buah pinang tersebut. 
Cara memanjat pohon pinang ialah dengan naik dan turun secara lurus pada salah satu sisi batang pohonnya. Pantangan ketika memanen buah pinang ialah tidak boleh memanjat sambil berputar pada batang pohon pinang. Selain itu, pohon pinang tidak boleh ditendang dengan sengaja oleh pemanennya. Secara tradisional, untuk menghilangkan efek mabuk dari mengonsumsi sirih pinang ialah dengan cara menjentikkan jari ke gigi (dikuti) beberapa kali dan memberikan gula pasir untuk diisap oleh orang yang sedang mabuk sirih-pinang.

Dalam bahasa daerah Loli, sirih disebut utta, dan pinang dikatakan winno. Namun, terdapat pula satu istilah yaitu pamama berarti sirih-pinang, untuk menyebut kedua benda tersebut (buah sirih dan buah pinang) secara bersamaan. Sedangkan kata mama mengacu pada kata kerja yaitu mengunyah (memakan) buah sirih dan buah pinang dicampur dengan kapur (kapu).

Penyebutan sirih-pinang dalam bahasa lokal mengisyaratkan bahwa kedua tanaman ini merupakan tanaman yang tumbuh dan berkembang di daerah tersebut. Hal ini menandakan pula bahwa penduduk sudah sangat akrab dan menganggap penting arti dari keberadaan sirih dan pinang dalam kehidupan mereka.

Tradisi bersirih pinang merupakan kebiasaan yang dilakukan oleh laki-laki maupun perempuan, sendiri ataupun bersama-sama, baik itu dalam hidup keseharian, memperingati ritus hidup dan berbagai praktik ritual adat.

\section{a. Sirih Pinang dalam Ritual Adat}

Pamama (sirih-pinang) merupakan perlengkapan wajib yang harus ada ketika melakukan ritual adat. Tidak hanya berupa materi dari sirih pinang itu sendiri, namun dalam syair adat ketika ritual tersebut pun, kata sirih pinang dilantunkan oleh rato sebagai pemimpin doa dalam ritual. Sebagai contoh ialah pada ritual noba dan wulla podu.

Ritual noba ialah salah satu bentuk ritual adat yang dilakukan untuk memohon restu dari Sang Pencipta dan para leluhur demi kelancaran dan keberkahan suatu keinginan atau pekerjaan, serta untuk mengetahui kehendak dari Sang Pencipta. Ritual ini biasanya dilakukan malam hari sebelum suatu kegiatan dilakukan. Dalam melakukan ritual ini diperlukan perlengkapan upacara berupa beras, sirihpinang dan seekor ayam. Pada saat ritual ini digelar, ayam akan disembelih oleh seorang rato pemimpin doa noba dan ia akan membaca tanda-tanda yang ada pada bulu ayam serta usus ayam tersebut. Pembacaan tanda ini untuk mengetahui apakah keinginan atau rencana kegiatan yang akan dilaksanakan akan berjalan baik atau tidak.

Selama ritual berlangsung, Rato noba melafalkan syair adat berisi doa sesuai maksud noba itu dilaksanakan. Kata sirih-pinang dilantunkan dalam pembuka dan penutup syair adat. Sebagai pembuka ritual diucapkan kalimat warasa wiasa soloka mama (ambil beras yang diberikan dan sirih pinang yang disajikan). Hal ini bermakna penyampaian beras dan sirih pinang untuk jiwa jiwa leluhur agar mendengar apa yang diinginkan dalam doa nya. Kemudian sebagai penutup syair adat, pada saat ritual selesai dilaksanakan, Rato noba mengucapkan wasi weru kapu mama yang bermakna bahwa kita akhiri doa dengan makan kapur, sirih dan pinang.

Ritual wulla poddu ialah ritual adat yang memiliki arti bulan suci, bulan sakral atau bulan pemali yang dilaksanakan selama satu bulan (sekitar bulan November) di Sumba Barat. Di dalamnya terdapat berbagai prosesi ritual adat yang dilaksanakan sesuai tahapan yang telah ditentukan. Bulan ini ialah bulan dimulainya tahun baru dalam budaya agraris orang Sumba di Sumba 
Barat. Pada bulan ini salah satu pantangannya ialah tidak boleh menyebutkan nama langsungnya terhadap barang yang dibutuhkan. Sebagai contoh untuk penyebutan sirihpinang, di hari biasa dan di kampung disebut utta-winno, tetapi ketika sedang berada di hutan untuk berburu masuk bulan pemali disebut dengan kata dereta. Upacara ini dilakukan sebagai media untuk mengungkapkan rasa syukur atas hasil panen yang telah dinikmati dan untuk memohon keberkahan atas kegiatan pertanian di masa yang akan datang. Dalam upacara ini pun diharuskan adanya sirih-pinang sebagai kelengkapan upacara. Selain itu, narasi syair adat terkait gambaran tradisi sirih pinang yang menjadi sajian bagi leluhur maupun bagi yang masih hidup dikumandangkan oleh Rato Rumata sebagai pemimpin ritualnya (Lihat Rothe : 2004).

\section{b. Sirih-Pinang dalam Ritus Hidup}

Dalam upacara yang berkaitan dengan ritus hidup orang Sumba, seperti kelahiran (pemberian nama), sunatan, perkawinan, kehamilan, dan kematian. Keberadaan sirih-pinang wajib ada. Dalam hal ini terutama terlihat pada prosesi perkawinan adat dan penguburan saat ada kematian. Hal tersebut menunjukkan bahwa sirih-pinang hadir pada acara yang berselimut kesenangan pada pernikahan, maupun kedukaan pada kematian.

Suatu perkawinan adat di Sumba ditujukan untuk membentuk keluarga dan rumah tangga baru, sekaligus juga menyatukan dua keluarga besar. Pada umumnya, proses perkawinan adat di Loli melalui beberapa tahapan. Secara umum, terdapat beberapa tahapan yang cukup memerlukan waktu hingga berbulan-bulan dalam acara pernikahan adat di Loli, yaitu ngidi pamama, weri kawedo, dutu mawinne dan namata kato wawawi. Keempat tahapan tersebut, dimulai dari membuka perasaan dari pihak laki-laki kepada pihak perempuan, meminang, menegosiasikan jumlah belis. pembayaran belis, memboyong pengantin perempuan ke rumah pihak laki-laki dan kunjungan keluarga pihak perempuan ke rumah baru anak perempuan yang telah menikah tersebut.

Salah satu tahapan perkawinan yang dinamakan ngidi pamama berarti "membawa sirih-pinang". Ia memiliki makna sebagai suatu lamaran (pinangan) dari keluarga pihak laki-laki kepada keluarga pihak perempuan. Dalam tahapan ini, pihak laki-laki membawa seekor kuda, sebilah parang dan buah sirih-pinang. Buah sirih dan pinang yang dibawa disebut dengan kobaka winno dan kabuka utta. Kata kobaka dan kabuka mengacu pada wadah untuk buah sirih dan pinang yang terbuat dari pelepah pinang yang diikat. Di samping pelamar laki-laki yang membawa sirih-pinang, pihak perempuan yang dilamar pun menyediakan sirih-pinang sebagai suguhan bagi semua orang yang hadir pada acara tersebut. Sirih-pinang sebagai hantaran dari pihak laki-laki mengisyaratkan suatu permohonan dan penghargaan, sedangkan penyambutan dari pihak perempuan menandakan penghormatan bagi yang datang. Suatu sikap saling menghargai dan menghormati dari kedua belah pihak yang akan melangsungkan pernikahan.

Terkait hal ini, Onvlee yang pada tahun 1940-1941 melawat ke Kampung Jaga Ngara di wilayah Loli, Sumba Barat (Saat ini terletak di wilayah administratif Kota Waikabubak), ketika sedang ada renovasi rumah besar (uma kalada). Ia mengasosiasikan antara setiap proses dalam pembangunan rumah dengan prosesi penyatuan hubungan antara pihak laki-laki dan perempuan dalam perkawinan. Dalam tulisannya ia mendeskripsikan bahwa setiap orang membawa sirih pinang dalam acara pesta perkawinan, baik dari pihak laki-laki maupun perempuan (Onvlee, 1983: 163). Dalam prosesi lainnya pun, selain 
tersebut di atas, ketersedian sirih-pinang, menjadi suatu hal yang wajib hadir. Baik dalam ritual prosesi perkawinan, maupun sebagai jamuan untuk orang yang hadir pada acara tersebut.

Selain dalam perkawinan adat, kehadiran sirih pinang terdapat dalam prosesi penguburan orang yang meninggal dunia. Dalam budaya Sumba yang mewarisi budaya megalitikum dan masih dipraktikan hingga saat ini, bentuk kuburnya ialah berupa kubur batu (kuburan yang terbuat dari batu) ${ }^{6}$. Penguburan dilakukan oleh keluarga besar orang yang meninggal. Dalam acara ini pihak keluarga melaksanakan ritual adat dan mengumpulkan banyak orang dari pihak keluarga, kerabat dan teman dari orang meninggal tersebut. Biasanya sebelum dimakamkan, jenazah akan disemayamkan beberapa hari di rumah duka, sembari keluarga menyiapkan segala sesuatu terkait prosesi penguburan secara adat.

Setiap hari ada orang yang melayat untuk menyampaikan rasa berkabung dan turut menyumbang kepada keluarga yang berduka dengan membawa hewan seperti kerbau, kuda, babi, ayam, kain Sumba, hingga uang. Pada acara itu, pihak tuan rumah akan menugaskan seorang perempuan dewasa di dekat pintu masuk rumah duka untuk memberikan sirihpinang kepada para pelayat yang datang. Hal ini dimaksudkan sebagai tanda penghormatan dan ungkapan terima kasih. Di samping itu, ketika dudukduduk di sekitar rumah duka, akan disuguhi pula minuman kopi atau teh; serta sirih pinang oleh anak-anak muda yang ditugasi menyediakan hidangan bagi para pelayat.Dalam proses penguburan, jenazah orang yang meninggal akan dimasukkan ke dalam kubur batu. Bersamaan dengan itu akan

\footnotetext{
${ }^{6}$ Saat ini, banyak kuburan baru yang terbuat dari semen karena pertimbangan biaya yang mahal dan waktu yang lama untuk memperoleh bahan batu kubur tersebut.
}

disertakan pula ke dalamnya beberapa benda sebagai bekal kuburnya. Bekal kubur, biasanya berupa, kain tenun Sumba, perhiasan, kaleku dan sirihpinang. Barang-barang yang dijadikan bekal kubur biasanya bergantung pada kesukaan (kebiasaaan) orang yang meninggal tersebut ketika masih hidup dan juga pada kemampuan dari keluarga yang ditinggalkannya.

\section{c. Sirih-Pinang dalam Kehidupan Sosial}

Sirih-pinang merupakan sajian yang pertama dan utama ketika berkunjung ke rumah orang Sumba. Ketika berkunjung ke rumah orang Sumba, tuan rumah akan menggelar tikar, mempersilahkan duduk, menyuguhkan sirih-pinang, menyajikan kopi Sumba, dan jika waktunya cukup senggang akan mempersilahkan makan nasi beserta lauk pauknya.

Ketersediaan sirih-pinang di rumah menjadi seperti kewajiban, baik itu untuk konsumsi sendiri, maupun untuk tamu yang datang. Namun jika ada tamu dan kebetulan tuan rumah tidak memilikinya, maka ia akan meminta ke tetangganya. Demikian juga sebaliknya, prinsip resiprositas berlaku dalam penyediaan sirih pinang, saling memberi dan saling menerima. Namun, jika tetap tidak mampu menyediakan sirih-pinang ketika ada tamu, maka ia akan meminta maaf pada tamu bahwa ia sedang tidak memiliki sirih-pinang sehingga tidak dapat menyuguhkannya.

Di sisi lain, ketika tuan rumah mengetahui bahwa orang yang bertamu tidak mengkonsumsi sirih pinang, maka ungkapan "mama diewamu" diucapkan sambil menyodorkan sirih-pinang sebagai tanda penghargaan atas kedatangannya. Ekspresi lisan "mama diewamu", (mama: sirih-pinang; dan diewamu: jiwamu) bukan berarti jiwamu yang menguyah sirih-pinang, tetapi merupakan tuturan simbolis yang memiliki makna penghormatan terhadap jiwa seseorang sebagai hakikat dari daya hidupnya. 
Kemudian tamu tersebut cukup mengucapkan terima kasih.

Dalam berbagai situasi di kehidupan sehari-hari, sirih pinang menjadi media bersosialisasi untuk membuka komunikasi, mengakrabkan hubungan sosial, dan mencairkan suasana serta membangun silaturahmi. Caranya dapat berupa saling menawarkan dan 'bertukar kaleku' agar mengambil sendiri sirihpinangnya. Hal ini menandakan bahwa penawaran sirih-pinang dilakukan dengan segenap hati, bukan basa-basi.

Onvlee menulis pada tahun 1933 (86 tahun yang lalu), terkait kebiasaan saling menawarkan sirih-pinang di Sumba tersebut:

"Laat blijken dat je van harte geeft en reik hem je sirihtas of mandje, zodat hij zelf nemen kan" (Onvlee, 1933: 32).

"Tunjukkan bahwa Anda memberi dengan sepenuh hati dan memberinya tas atau keranjang sirih Anda, sehingga ia dapat mengambilnya sendiri"

Dan etika bagi yang menerima tawaran tersebut agar dinilai cukup sadar diri:

"Reken niet op het sirihmandje (de sirihtas) van een ander. Neem geen handvol uit het mandje (de tas) van anderen. Neem niet het laatste uit het mandje (de tas) van anderen" (Onvlee, 1933: 31).

"Jangan mengandalkan keranjang sirih (tas sirih) orang lain. Jangan mengambil segenggam penuh dari keranjang (tas) orang lain. Jangan mengambil yang terakhir dari keranjang (tas) orang lain"

Dengan kata lain, nilai budaya yang mengadung kesopanan dari etika kebiasaan menawarkan sirih pinang terwariskan hingga kini.

Sirih pinang juga, selalu hadir dalam situasi ketika ada kerja gotong royong (pawoda) yang melibatkan banyak orang. Baik itu untuk kepentingan pribadi maupun komunal, seperti kerja kebun, membangun jalan atau mendirikan rumah. Hal ini sebagai ungkapan terima kasih dan dapat menambah semangat bekerja.

Sirih-pinang berfungsi pula sebagai media dalam upaya mendamaikan orang yang berkonflik. Kehadiran sirih pinang mencairkan dan menghangatkan suasana. Hal ini sering dimanfaatkan oleh pihak penengah untuk mendamaikan pihakpihak yang sedang bertikai. Selain itu, makan sirih pinang bersama dapat menjadi penanda, apakah konflik yang ada sudah mereda atau belum. Hal ini seperti diceritakan oleh seorang mantan lurah dan camat yang ketika menjabat, bertugas menengahi seteru warganya, sebagai berikut:

"Kita kasih sirih-pinang. Kalau dia (yang berkonflik) sudah mau ambil (sirih-pinang) dan makan sirihpinang yang sama. Selesai. Jadi kalau dia tidak mau ambil sirih pinang yang kita sorong, berarti masih ada rasa tidak nyaman. Ketika sirih-pinang diambil dan dimakan bersama-sama, nyaman dia (yang berkonflik).”

Pemerintah Daerah Sumba Barat menggunakan tradisi sirih pinang dalam penyambutan tamu pada acara formal dan seremonial sebagai sajian khas sumba. Penyuguhan sirih-pinang dalam acara formal ini mengandung aspek simbolis penerimaan dengan tangan terbuka dan penghormatan bagi tamu dari tuan rumah. Hal ini dimaksudkan untuk menampilkan keramahtamahan dari budaya setempat.

Sirih-pinang dalam kehidupan sosial masyarakat Sumba seperti yang telah dipaparkan sebelumnya, memperlihatkan beragam fungsi simbolis dalam konteks budayanya. Hal ini seperti yang diungkapkan oleh Foster \& Anderson 
(1986, 317-322) mengenai peranan simbolik dari makanan, yaitu sebagai ungkapan ikatan sosial, sebagai ungkapan kesetiakawanan kelompok, untuk ketenangan jiwa dan simbolisme makanan dalam bahasa.

\section{d. Sirih - Pinang untuk Pengobatan}

Warga Sobawawi memiliki pengetahuan lokal yang secara turun temurun diwariskan oleh pendahulunya. Pengetahuan tersebut terkait dengan beragam fungsi pengobatan dari sirihpinang. Dalam aspek ini, sirih-pinang digunakan untuk mengobati luka luar agar cepat kering, sakit perut dan mual, serta sebagai obat penenang. Selain itu, sirih-pinang juga digunakan untuk kepentingan pengobatan dan penangkal dari penyakit yang bersifat supranatural.

\section{e. Sirih Pinang untuk Leluhur}

Dalam kepercayaan Marapu, leluhur yang sudah wafat, jiwanya diyakini tetap tinggal di dalam rumah bersama keluarga yang masih hidup. Mereka dipercaya akan menjaga, melindungi dan membantu keluarga yang masih hidup di dunia ini.

Ketika ada perayaan adat ataupun urusan yang menyangkut keluarganya, maka kepada jiwa-jiwa leluhur ini pulalah orang Sumba menyajikan sirihpinang sebagai simbol permohonan agar diberi restu dan kelancaran urusan, sekaligus penghormatan kepada leluhurnya. Caranya ialah dengan memasukkan sirih-pinang ke dalam kaleku yang disediakan khusus di tiang rumah untuk roh-roh leluhur yang telah tiada. Kaleku ini biasanya berupa kaleku milik almarhum yang sering digunakan semasa hidupnya. Selain itu, orang Sumba juga menempatkan sesaji berupa sirih-pinang di atas kubur batu orang tua dan leluhurnya. Hal ini bertujuan untuk memberitahukan niat mereka dan meminta restu dari leluhur.

Dalam budaya Sumba, terdapat kewajiban-kewajiban kekerabatan dengan prinsip resiprositas untuk saling membantu dalam berbagai urusan, terutama adat, seperti saat perkawinan dan kematian. Ketika ada orang yang meninggal dunia, kelompok-kelompok kerabat orang yang meninggal datang membawa dan memberikan barang adat seperti kuda, kerbau, babi atau kain tenun. Demikian pula sebaliknya, jika pihak yang membawa (memberi) hewan tersebut di atas meninggal, harus dibalas setara dengan apa yang telah diterima oleh pihak yang berduka tadi. Hewanhewan tadi dipotong untuk keperluan ritual dan konsumsi orang yang hadir. Penyembelihan hewan untuk kepentingan ritual ini bertujuan untuk membekali arwah yang dikuburkan mencapai dunia para leluhur sesuai dengan kepercayaan Marapu.

Prinsip resiprositas tersebut di atas, berlaku juga dalam acara perkawinan. Keluarga besar pihak laki-laki yang akan menikah saling menyumbang untuk membayarkan belis (mas kawin) yang berupa kuda, kerbau, babi, parang dan kain tenun. Pun untuk keperluan ritual adat atau pesta sewaktu acara berlangsung seperti kerbau, babi, beras, sirih-pinang dan lain sebagainya.

Sebelum acara yang dimaksud dilaksanakan, pihak yang berkepentingan mengumpulkan keluarga besarnya. Dalam hal ini, untuk membicarakan mengenai kesediaan dan kesanggupan untuk membantu terlaksananya acara tersebut, misalkan membawa kerbau, kuda atau babi. Kesanggupan pihak yang akan membantu, diutarakan dan disertai dengan sodoran sirih-pinang dalam piring pada pertemuan tersebut. Pertemuan keluarga ini, dipercayai dihadiri pula oleh leluhur mereka yang telah tiada. Menurut tokoh adat setempat, dalam konteks hukum saat ini "sirih-pinang itu diibaratkan sebagai tanda tangan di atas materai 12.000,-, bukan 6000 lagi, tapi 12.000. sebagai tanda jadi dan harus ditepati". Jika kesanggupan yang telah diucapkan dan disahkan oleh kehadiran sirih-pinang, serta disaksikan oleh pihak 
keluarga dan jiwa-jiwa leluhur yang hadir, itu tidak terpenuhi, maka akan berakibat pada "perasaan malu yang mendalam dan jatuhnya harga diri". Pun, hal ini dipercaya dapat berakibat terjadinya hal yang "kurang baik" bagi yang tidak menepati janjinya.

Dalam setiap ritualnya, termasuk pada upacara adat perkawinan maupun kematian, arwah leluhur (marapu) menjadi perantara antara orang yang masih hidup dengan kekuatan tertinggi Mawolu-Marawi. Jika yang hidup tidak memperlakukan marapu sebagaimana mestinya sesuai tradisi, maka dipercaya akan timbul musibah bagi yang melanggarnya.

Dalam konteks ritual adat dan kewajiban kekerabatan tersebut di atas, terlihat bahwa moralitas resiprositas terjadi tidak hanya antara kerabat yang masih hidup, tetapi juga dengan kerabat yang telah meninggal dunia. Di sisi lain, keberadaan sirih-pinang menjadi penanda penting dalam situasi tersebut.

\section{f. Sirih Pinang untuk Pengembangan Ekonomi}

Sirih dan pinang merupakan suatu komoditas dagang di Sumba Barat. Harganya fluktuatif tergantung jumlah ketersediaan barang di pasaran. Hal ini berhubungan erat dengan waktu panen dan acara yang memerlukan sirih-pinang dalam jumlah banyak, seperti dalam proses perkawinan dan kematian.

Penjual di pasar menjual dalam jumlah besar maupun eceran. Seikat sirih berisi 10 buah dijual dengan harga $\mathrm{Rp}$ 5.000,- dan semangkuk kecil pinang kering dihargai Rp 5.000,-. Namun jika membeli satu kilogram dihargai $\mathrm{Rp}$ $70.000,-$. Ada pula yang menjual dalam bentuk paketan seharga Rp 5.000,-, yang terdiri dari tiga buah sirih dan segenggam kecil pinang kering atau beberapa buah pinang muda. Di samping itu, kapur dijual terpisah dalam bentuk bungkus plastik kecil seharga Rp 2.000,-/bungkus.
Di tingkat lokal kabupaten, terdapat beragam jalur distribusi buah sirih dan pinang untuk sampai dari kebun petani ke konsumen, yaitu (1) Petani - Konsumen; (2) Petani - Pedagang Pengumpul Lokal - Konsumen; (3) Petani - Pedagang Pengumpul Lokal - Pedagang Pengecer Konsumen. Hal ini, menunjukkan potensi ekonomi dari sirih pinang, baik sebagai tambahan pendapatan bagi petani, maupun peluang ekonomi bagi pedagang. Untuk memenuhi kebutuhan sirih-pinang di Sumba Barat, selain dari tingkat lokal, juga diisi oleh pasokan pinang dari luar daerah dan luar pulau.

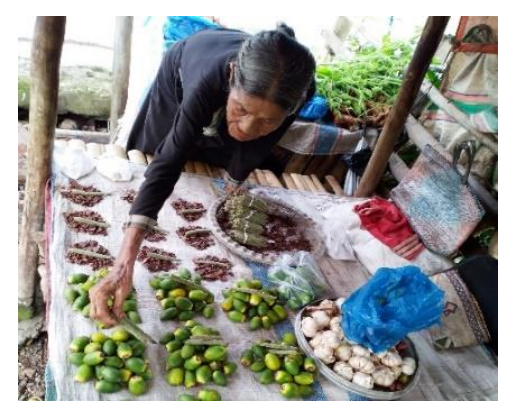

Gambar 3. Pedagang pengecer sirih pinang menyiapkan dagangan di lapak miliknya. Sumber: Arief, 2019.

Pada tahun 2018, pemerintah daerah setempat, melalui Badan Penelitian dan Pengembangan Kabupaten Sumba Barat yang bekerjasama dengan Universitas Nusa Cendana melakukan kajian terkait pengembangan tanaman pinang. Studi tersebut menghasilkan rekomendasi bahwa pengembangan budidaya tanaman pinang di wilayah Kabupaten Sumba Barat layak untuk dilakukan dan berpotensi untuk peningkatan perekonomian warga setempat.

\section{g. Budaya Material dari Sirih Pinang}

Budaya sirih-pinang menghasilkan beragam budaya materi yang digunakan sebagai alat bantu untuk menyimpan, membawa dan memudahkan memakannya.

a. Tempat kapur digunakan untuk wadah kapur. Biasanya tempat kapur 
ini terbuat dari tanduk kerbau dan bambu. Kini ada juga tempat kapur yang terbuat dari paralon yang dibalut dan dihiasi dengan benang berwarna-warni. Tempat kapur dihiasi juga dengan beragam ukiran motif hias khas sumba, seperti gambar kerbau dan mamuli, untuk menampilkan kreativitas si pembuatnya dan manambah kesan estetis ketika dilihat.

b. Ngow (lesung) terbuat dari tanduk kerbau dan Alu (alu) terbuat dari logam untuk menumbuk sirihpinang. Alat ini digunakan sebagai alat bantu untuk melumatkan sirih pinang sebelum dikonsumsi. Biasanya digunakan oleh orang lanjut usia yang tidak kuat menggigit dan mengunyah sirih-pinang. Cara menggunakannya ialah sirih, pinang dimasukkan ke dalam ngow, kemudian ditumbuk hingga halus. Setelah itu ditambahkan kapur secukupnya, hingga rasanya pas sesuai selera.

c. Kaleku (tas sirih pinang). Tas ini digunakan untuk menyimpan dan membawa sirih pinang. Bentuknya persegi panjang yang dapat dijinjing maupun dilengkapi tali untuk diselempangkan pada bahu. Biasanya terbuat dari anyaman daun pandan atau ada juga yang terbuat dari kulit kayu. Bagian luar kaleku juga dipercantik dengan beragam motif hias khas Sumba, seperti gambar mamuli, kerbau, lekota, kerewino dan lain sebagainya. Pada kaleku, terdapat perbedaan jenis tali selempang antara kaleku untuk lakilaki dan untuk perempuan. Kaleku yang digunakan oleh laki-laki menggunakan kain sebagai tali selempangnya. Sedangkan kaleku untuk perempuan, bertali biasa sesuai bahan anyaman kaleku-nya, ataupun tanpa menggunakan tali selempang. d. Kuolaka (wadah atau piring anyaman untuk menghidangkan sirih pinang). Biasanya terbuat dari anyaman daun pandan atau daun lontar. Selain itu, saat ini untuk menghidangkan sirih pinang digunakan piring yang terbuat dari seng atau beling. Hal ini dilakukan jika tidak ada koulaka.

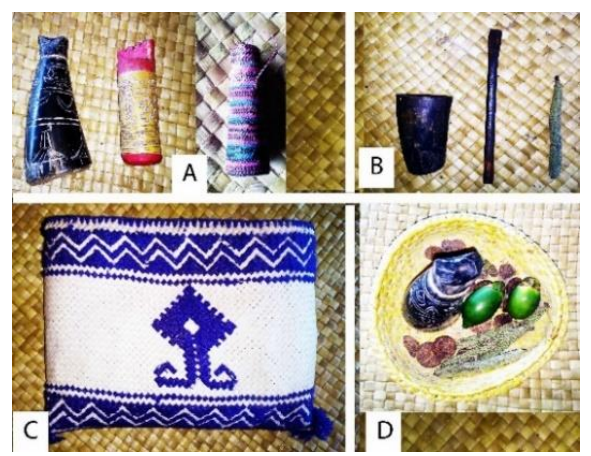

Gambar 4. Budaya material terkait sirih pinang: A. Tempat kapur; B. Ngow dan alu; C. Kaleku; D. Kuolaka. Sumber: Arief, 2019.

\section{Budaya Sirih - Pinang sebagai Warisan Budaya Takbenda}

Berdasarkan uraian mengenai budaya sirih pinang di Sobawawi, Loli, Sumba Barat, Nusa Tenggara Timur, maka dapat disimpulkan bahwa budaya sirihpinang dapat dikategorikan sebagai sumber daya budaya takbenda. Hal ini mengacu pada kategori dari Blankeney ${ }^{7}$ mengenai kriteria dari objek sumber daya budaya takbenda, yang diantaranya ialah mengandung nilai tradisional, sebagai living culture, diwariskan antar generasi, kontekstual dengan lingkungannya, serta berfungsi sebagai identitas sosial dan budaya.

Kemudian, terkait dengan definisi warisan budaya takbenda berdasarkan Convention for the Safeguarding of the Intangible Cultural Heritage, yang meliputi "praktik, representasi, ekspresi, pengetahuan dan keterampilan"

\footnotetext{
${ }^{7}$ Uraian lengkapnya dapat dilihat pada bagian pendahuluan tulisan ini
} 
masyarakat atau kelompok atau individu yang diteruskan antargenerasi. Budaya sirih pinang dapat masuk dalam kategori sebagai warisan budaya takbenda. Dalam hal ini termasuk ke dalam kategori karya budaya $^{8}$ berupa 'pengetahuan dan kebiasaan perilaku mengenai alam dan semesta, termasuk pengetahuan tradisional, kearifan lokal, pengobatan tradisional'.

\section{PENUTUP}

Sirih pinang merupakan simbol budaya penting bagi orang sumba. Sirih pinang hadir dalam keseharian hidup orang sumba, dari kesenangan pribadi hingga urusan komunal; dalam hubungan dengan sesama yang masih hidup hingga leluhur yang telah meninggal dunia; dari acara formal, informal hingga ritual adat. Kesemua itu melibatkan sirih pinang. Sirih pinang menjadi sajian khas orang Sumba.

Kajian ini menemukan bahwa sirih pinang dalam budaya Sumba memiliki beragam fungsi yaitu sosial, budaya, ekonomi dan pengobatan. Selain itu, dalam budaya sirih pinang mengandung nilainilai budaya orang Sumba yang terkait erat dengan kepercayaan Marapu, tempat

${ }^{8}$ Berdasarkan konvensi UNESCO tahun 2003 mengenai Safeguarding of the Intangible Cultural Heritage, ranah warisan budaya takbenda mencakup lima kategori karya budaya: (1) tradisi dan ekspresi lisan, termasuk bahasa sebagai wahana warisan budaya takbenda, termasuk cerita rakyat, naskah kuno, dan permainan tradisional; (2) Seni pertunjukan, termasuk seni visual, seni teater, seni suara, seni tari, seni musik dan film; (3) Adat istiadat masyarakat, ritus, dan perayaanperayaan, sistem ekonomi tradisional, sistem organisasi sosial, dan upacara tradisional; (4) pengetahuan dan kebiasaan perilaku mengenai alam dan semesta, termasuk pengetahuan tradisional, kearifan lokal, pengobatan tradisional;(5) Kemahiran kerajinan tradional, termasuk seni lukis, seni pahat/ukir, arsitektur tradisional, makanan dan minuman tradisional, pakaian tradisional, aksesoris tradisional, makanan dan minuman tradisional, moda transportasi tradisional. tinggal dan ikatan kekerabatan. Budaya sirih pinang menjadi simbol penting bagi orang Sumba.

Dengan melihat arti penting budaya sirih pinang bagi orang Sumba, seperti tergambarkan dalam tulisan ini yang mengambil studi kasus di Sumba Barat. Di samping itu juga, melihat adanya fenomena memudarnya budaya sirih pinang di beberapa tempat di Nusantara. Maka untuk melestarikan dan mengantisipasi pudarnya budaya sirih pinang di Sumba Barat tersebut diperlukan adanya upaya pelestarian (perlindungan, pengembangan dan pemanfaatan) terhadap budaya sirih pinang ini. Salah satu peluang pelestariannya ialah dengan memanfaatkan sistem perlindungan hukum sumber daya budaya takbenda, yaitu melalui warisan budaya takbenda.

Berdasarkan temuan dari penelitian ini, sebagai salah satu upaya pelestarian budaya sirih pinang ialah dengan cara pengajuan budaya sirih pinang di Sumba Barat sebagai warisan budaya takbenda di Indonesia. Berdasarkan studi pustaka yang telah disebutkan pada bagian pendahuluan tulisan ini, terlihat bahwa tidak hanya di Sumba Barat saja, budaya ini hidup dan berkembang, tetapi juga di seluruh pulau Sumba. Selain itu, terdapat beberapa kelompok masyarakat yang tersebar dalam wilayah budaya yang berbeda yang masih menghidupi budaya sirih pinang, dengan ragam praktik dan pengetahuan serta penamaan menurut budaya lokal tempatannya, seperti di Seram, Manggarai, dan Papua. Dengan pertimbangan tersebut, maka dapat dilakukan pengajuan budaya sirih pinang sebagai warisan budaya takbenda milik bersama, sesuai dengan masyarakat yang menghidupi budaya sirih pinang di Indonesia.

Dengan pengajuan budaya sirih pinang sebagai warisan budaya takbenda Indonesia, diharapkan mata budaya ini mendapatkan pengakuan dan penetapan secara legal formal, sehingga akan menjamin adanya perlindungan pada mata budaya tersebut agar lestari, dan adanya 
penghormatan pada pemangku warisan budaya tersebut.

Selanjutnya, melalui pengakuan dan penetapan sirih-pinang sebagai warisan budaya takbenda, secara tidak langsung, diharapkan dapat menjaga pula kelestarian tanaman sirih dan pinang di alam. Di samping itu, pelindungan Warisan Budaya Takbenda (WBTB) dapat menjadi titik tolak pelindungan-pelindungan lain, termasuk pelindungan HKI (Hak Kekayaan Intelektual) komunal Ekspresi Budaya Tradisional, yang dapat secara langsung meningkatkan nilai ekonomi suatu mata budaya.

\section{DAFTAR SUMBER}

\section{Jurnal, Teisi, dan Disertasi}

Ayu, M. R., Permata, R. R. \& Rafanti, L. "Sistem Perlindungan Sumber Daya Budaya Takbenda Di Palembang, Sumatera Selatan, Indonesia" dalam Mimbar Hukum Volume 29 Nomor 2. Juni 2017. Hlm. 205-220.

Barokah, S. 2016. An Ethnographic Investigation of Master Slave Relation in Sumba, Indonesia. Tesis. International Institute of Social Studies.

Ellen, R. "Nuaulu Betel Chewing: Ethnobotany, Technique and Cultural Significance" dalam Cakalele Vol. 2 Nomor 2. 1991. Hlm. 97-122.

Iskandar, J., Iskandar, B. S., \& Partasasmita, R. "Review: The Impact of Social and Economic Change on Domesticated Plant Diversity With Special Reference To Wet Rice Field and Home-Garden Farming of West Java, Indonesia" dalam Jurnal Biodiversitas Volume 19 Nomor 2. March 2018. Hlm. 565-577.

Nugroho, A. R. 2016. Dinamika Budaya Konsumsi Pinang Dalam Pembentukan Ruang Publik Kota Manokwari. Tesis. Yogyakarta: Magister Ilmu Religi dan Budaya Universitas Sanata Dharma Yogyakarta

Reid, A. "From Betel-Chewing To TobaccoSmoking In Indonesia" dalam The Journal of Asian Studies Volume XLIV Nomor 3. May 1985. Hlm. 529-47.
Rooney, F.D. 1995. Betel Chewing In South East Asia. Makalah dipresentasikan dalam The Centre National De La Recherce Scientifigue. Lyon, France.

Rothe, E. 2004. Wulla Poddu: Bitterer Monat, Monat der Tabus, Monat des Heiligen, Monat des Neuen Jahres in Loli in der Siedlung Tarung-Waitabar, Amtsbezirk der Stadt Waikabubak in Loli, Regierungsbezirk Westsumba, Provinz. Nusa Tenggara Timur, Indonesien (Wulla Poddu: Bulan Pahit, Bulan Larangan, Bulan Pemali Keramat, Bulan Tahun Baru Loli di Kampung Tarung-Waitabar, Kecamatan Kota Waikabubak/Loli, Kabupaten Sumba Barat, Propinsi Nusa Tenggara TimurIndonesia). Disertasi. Munich: LudwigMaximilians-Universität München.

Saka, N. T. 2001. Etnobotani Sirih-Pinang dalam Kehidupan Suku Ruteng di Kabupaten Manggarai. Tesis. Bogor: Institut Pertanian Bogor.

Soeriadiredja, P. "Marapu: Konstruksi Identitas Budaya Orang Sumba, NTT" dalam Jurnal Antropologi Indonesia Volume 34 Nomor 1. Januari-Juni 2013. Hlm. 59-74.

\section{Buku}

Ayu Palar, M. R. 2018.

"The Protection of Intangible Cultural Resources in the Indonesian Legal System" dalam Christoph Antons \& William Logan (Ed), Intellectual Property, Cultural Property and Intangible Cultural Heritage. Routledge: New York.

Bamualim, A. U. 2017.

Mengenal Sumba Barat: The Next Travel Destination. Waikabubak: Dinas Kebudayaan dan Pariwisata Kabupaten Sumba Barat.

BPS Kabupaten Sumba Barat. 2018. Kecamatan Loli Dalam Angka 2018.

BPS Kabupaten Sumba Barat. 2018. Kabupaten Sumba Barat Dalam Angka 2018.

Burkill, I.H. 1935.

A Dictionary of The Economic Products Of The Malay Peninsula, Vol. 
I dan II. London: Governments of the Straits of Settlements and Federated Malay States by the Crown Agents for Colonies.

Forth, G. L. 1981.

Rindi: An Ethnographic Study of a Traditional Domain in Eastern Sumba. The Hague: Martinus Nijhoff.

Foster, G.M., \& Anderson, B. G. 1986. Antropologi Kesehatan. Diterjemahkan dari buku Medical Anthropology oleh Priyanti Pakan Suryadarma dan Meuitia F. Hatta Swasono. Jakarta: UI-Press.

Heyne, K. 1987. Tumbuhan Berguna Indonesia, Jilid I dan II. Terjemahan. Jakarta: Badan litbang Kehutanan Indonesia.

Huberman, A. M., \& Miles, M. B. 2009. "Manajemen Data Dan Metode Analisis" dalam Denzin, N. K., \& Lincoln, Y. S. (Eds.). Handbook of Qualitative Research. Pustaka Pelajar: Yogyakarta. Halaman 591 - 612.

Onvlee, L. 1933.

Na huri hapa. In Cultuur Als Antwoord. Verhadenlingen van het KTLV, 66. The Hague: Martinus Nijhoff. 1983.

"The Construction of The Mangili Dam: Notes On The Social Organization Of Eastern Sumba" dalam P.E. de Josselin de Jong (ed), Structural Anthropology In The Netherlands. Dordrecht: Foris Publications Holand. Halaman 151-163.

Reid, A. 2014.

Asia Tenggara dalam Kurun Niaga 1450-1680 Jilid 1: Tanah di Bawah Angin. Jakarta: Yayasan Pustaka Obor Indonesia.

Rudgley, R. 2005.

"Psychoactive Plants" dalam Ghillean Prance \& Mark Nesbit (ed). The Cultural History of Plants. New York: Routledge. Halaman 191-204.

Sedyawati, E. 2014.

Prinsip-Prinsip Manajemen Sumber Daya Budaya dalam Kebudayaan di Nusantara - Dari Tortor sampai
Industri Budaya. Jakarta: Komunitas Bambu.

Solihin, L. 2018.

"Sirih Pinang dalam Kebudayaan Melayu" dalam Afthonul Afif, Khidir Marsanto, dan Lukman Solihin (Ed), Dari Melayu Menjadi Indonesia. Yogyakarta: Basabasi.

Vel, J. 2010.

Ekonomi-Uma: Penerapan Adat dalam Dinamika Ekonomi Berbasis Kekerabatan. Terjemahan. Jakarta: HuMa; Van Vollenhoven Institute; KITLV.

Waluyo, Harry dkk. (Tim Penyusun). 2009. Buku Panduan Praktis Pencatatan Warisan Budaya Takbenda Indonesia. Jakarta: Departemen Kebudayaan dan Pariwisata bekerjasama dengan Kantor UNESCO Jakarta. 
